ENCYCLOPEDDE Encyclopédie berbère

BERBERE

17| 1996

17 | Douiret - Eropaei

\title{
Druitae
}

\section{J. Desanges}

\section{OpenEdition}

Journals

Édition électronique

URL : http://journals.openedition.org/encyclopedieberbere/2120

DOI : 10.4000/encyclopedieberbere. 2120

ISSN : 2262-7197

\section{Éditeur}

Peeters Publishers

\section{Édition imprimée}

Date de publication : 1 août 1996

Pagination : 2555

ISBN : 2-85744-872-4

ISSN : 1015-7344

\section{Référence électronique}

J. Desanges, « Druitae », Encyclopédie berbère [En ligne], 17 | 1996, document D94, mis en ligne le 01 juin 2011, consulté le 24 septembre 2020. URL : http://journals.openedition.org/encyclopedieberbere/ 2120 ; DOI : https://doi.org/10.4000/encyclopedieberbere.2120

Ce document a été généré automatiquement le 24 septembre 2020

(c) Tous droits réservés 


\section{Druitae}

\section{J. Desanges}

1 Tribu de l'ouest de la Maurétanie Césarienne selon Ptolémée (IV, 2, 5, Müller, p. 603), qui la situe « sous » les Sorae, eux-mêmes signalés comme les voisins méridionaux de la tribu des Masaesyles. Peut-être faut-il mettre le nom des Druitae en rapport avec le nom grec du chêne (drus) ou celui d'une variété de cyprès (kuparissos druirtēs : Théophr., C.P., I, 2, 2), comme, de toute évidence, le nom des Asphodelodeis* est forgé sur celui de l'asphodèle. C. Müller (éd. de Ptol. I, 2, p. 603, col. b) a suggéré de corriger Druitae en Duritae; il s'agirait alors des habitants de la chaîne du Duris, nom grec de l'Atlas d'après Strabon (XVII, 3, 2, C 825). L'hypothèse est ingénieuse. Mais on pourrait tout aussi bien rapprocher les Druitae du nom du fleuve Dryis, qui, selon Vitruve (VIII, 2, 6), prend sa source dans l'Atlas septentrional.

INDEX

Mots-clés : Agriculture, Antiquité, Tribu 